\title{
Early Intimations of Colonialism in the 17th century: William Shakespeare's Othello and The Tempest, John Fletcher's The Island Princess, Aphra Behn's Oroonoko
}

\author{
Hilal Kaya \\ Middle East Technical University
}

\section{Introduction}

The seventeenth century is like a transition period for many countries as several changes concerning culture, society, and literature took place. These changes urged several nations to know 'others' more. England, as one of the powerful countries in that time, also encountered the world's incentives for knowledge, economic resources and religious objectives, briefly, people travelled for 'power'. The word power, which will be studied in the following pages, signifies energy, money, right and the force to 'move' and 'lead' those who are power-less in terms of politics. The English people travelled foreign lands and shared their knowledge by writing. In other words, the purpose of writing about other lands and recounting one's experiences of foreign travel is that these representations increase the reader's knowledge of other cultures providing useful information. In this study, the early intimations of colonialism and some seventeenth century works which can be regarded as literary texts displaying travels' and colonialism's influences on literature will be highlighted. Therefore, the importance and purpose of colonialism will be studied through Shakespeare's Othello, The Tempest, Fletcher's The Island Princess, and Behn's Oroonoko. However, this study will not attempt to provide a historical assessment of early modern travel writing or represent every aspect of texts which depicted foreign people, cultures and places. Rather, it will explore one important purpose of such 
texts; namely, the way in which they reflected upon contemporary English political issues and controversies in terms of attaining power.

For the purpose of travels, Markley asserts,

The widespread perception in the first half of the seventeenth century that England's resources were inadequate to support its population, or that nature itself had been corrupted by mankind's sins, placed the burden on international trade to solve complex ecological, demographic, and economic crises. (5)

As Bush also states,

For Protestant Englishmen of the sixteenth and seventeenth centuries all these motives except the first [the motives of pilgrim, ecclesiastic, scholar, businessman, diplomat, soldier, and mere tourist] were operating with greater urgency than ever. The political and commercial conditions of Europe, combined with the ideals of Renaissance humanism, gave a new importance to study of the history, policy, language, and manners of foreign countries as a preparation for public service and international trade. (170-1)

Although in the seventeenth century, people did not, of course, use these terms 'travel literature or colonialism' for this type of writing, it is now named and accepted as a ubiquitous but "unremarkable category in the English-speaking world" (Hadfield 1). As Hadfield argues, "very little travel writing as such [unlike subsequent travel writings of the seventeenth century, these were not opposed by other writers] was produced until the start of the seventeenth century." (4) In this sense, Francis Bacon who used the term 'plantation' or 'dominion' as synonyms for 'colony' in his thirty-second essay, entitled Of Plantation should be remembered. As Finley also puts it,

Today the dominant sense of 'plantation' is that of a large estate, often with monoculture and usually located in tropical or semi-tropical regions-cotton plantation, 
sugar plantation, tea plantation. That is the etymologically strict sense. But from at least the sixteenth century into the nineteenth, in English the word 'plantation' took a turn that was very rare in ancient and Medieval Latin and effectively unknown in modern Romance languages. (170)

In his essay Bacon describes the 'proper' ways of planting and plantation because 'people', not crops, were the objects of the 'planting' and the 'transplanting' in his lifetime. This idea is evident in the following excerpts from his essay:

The people wherewith you plant ought to be gardeners, ploughmen, labourers, smiths, carpenters, joiners, fishermen, fowlers, with some few apothecaries, surgeons, cooks, and bakers. In a country of plantation, first look about what kind of victual the country yields of itself to hand; as chestnuts, walnuts, pineapples, olives, dates, plums, cherries, wild honey, and the like; and make use of them... (from The Norton Anthology 1264)

When the plantation grows to strength, then it is time to plant with women as well as with men; that the plantation may spread into generations, and not be ever pieced from without. It is the sinfullest thing in the world to forsake or destitute a plantation once in forwardness; for besides the dishonour, it is the guiltiness of blood of many commiserable persons. (from The Norton Anthology 1265)

In the early seventeenth century, the topic of colonies took on greatly increased practical importance in England because of the establishment of the first permanent English settlements in the New World. Thus, it can be argued that such writings were produced out of the need to struggle with the victories of other rival nations (Spain and Portugal) to protect the English independence. 


\section{Power/Knowledge and Colonialism: Foucault and Nietzsche}

There is a genuinely and tightly established relationship between 'power/knowledge' and 'colonialism' because the end product of colonialism is knowledge which equals with power in general. In other words, power is based on and makes use of knowledge.

Although it is not directly related with the topic of this study, Michel Foucault and Friedrich Nietzsche and their long lasting ideas about the concept 'power' should be mentioned when the concept 'power-knowledge' is concerned. Considering their importance in the field Foucault and Nietzsche will respectively be mentioned briefly. For Foucault, as Dreyfus asserts,

Power, like Heidegger's being, is no fixed entity or institution, but is incarnated in historical social practices. "One needs to be nominalistic," he tells us, "power is not an institution, and not a structure; neither is it a certain strength we are endowed with; it is the name that one attributes to a complex strategical situation in a particular society." This strategical situation arises from specific individuals and groups opposing one another. These actions, taken together, open a social space in which people, things, and the real are defined. Like the clearing, power is productive. Foucault tells us: "[P]ower produces; it produces reality," that is, it determines what it makes sense to believe and to do. (Internet)

In the literary texts studied in this paper the power relations between the coloniser and the colonised will be handled from the afore-mentioned perspective of Foucault as Foucault takes,

[power] is everywhere not because it embraces everything, but because it comes from everywhere. And "Power," insofar as it is permanent, repetitious, inert, and self-reproducing, is simply the over-all effect that emerges from all these mobilities, the concatenation that rests on each of them and seeks in turn to arrest their movement ... power is not an institution, and not a 
structure; neither is it a certain strength we are endowed with; it is the name that one attributes to a complex strategical situation in a particular society. (Foucault: 1990 93)

As power means "relations, a more-or-less organised, hierarchical, co-ordinated cluster of relations" (Gordon 198), it can be taken as the conflict between two (or more) opposing groups, or the discourse of producing 'a threatening other'. From this angle, power becomes a concept which is suitable to be applied to the colonial discourse.

The other significant thinker, Nietzsche, and his one of the prominent concepts in philosophy, 'the will to power' or 'der wille zur macht' in German should be recalled. In his book Thus Spoke Zarathustra Nietzsche underlines that many people have always had numerous goals or virtues, and these virtues are gained as they have been driven by the will to power. They do not only want to exceed others' power but they also want to have more power than they have. In the part called "The Thousand and One Goals" Zarathustra states that

Wherever I found a living thing, there found I Will to Power; and even in the will of the servant found I the will to be master. (99)

That to the stronger the weaker shall serve-thereto persuadeth he his will who would be master over a still weaker one. That delight alone he is unwilling to forego. (99)

Only where there is life, is there also will: not, however, Will to Life, but—so teach I thee-Will to Power. (100)

Nietzsche was influenced by Schopenhauer who puts a central emphasis on will and in particular has a concept of the 'will to live'. Before Nietzsche, Schopenhauer explained that the universe and everything in it is driven by a primordial will to live, which results in all living creatures' desire to avoid death and procreate. For Schopenhauer, this will is the most fundamental aspect of 
reality-more fundamental even than being. Therefore, Nietzsche proposed the will to power as the main driving force in man; achievement, ambition, the striving to reach the highest possible position in life, these are all manifestations of the will to power. Accordingly, in colonial discourse power is an important impulse that has urged people to take action for the sake of gaining more power. The concept of power can be handled in several different contexts, and one of these important areas where power is a remarkably dominant phenomenon is the seventeenth century politics or more specifically activities of 'plantation' (in Baconian sense).

In fact, works produced in the seventeenth century can be read in many ways, and one of which should be the vantage point of the reader for the sake of restriction and relevancy. It can also be suggested that such writings can be designated as 'colonial'. Before the colonial connotations in the literary texts of the seventeenth century are sorted out, one should have a quick look at what the start of English colonial literature was like, as an introduction to the topic.

Colonialism indicates a period of history from the fifteenth to the twentieth century when people from Europe built colonies on other continents. This period of time is also known as the Age of Discoveries. As Horvath defines colonialism, "it refers to that form of intergroup domination in which setters in significant number migrate permanently to the colony from the colonizing power." (47) Moreover, the word 'colonial' which is used in this study refers to the specific sense of promoting and maintaining colonies. That is, a settlement of people from one territory in another one. In this sense, it is similar to colonialism. As Finley argues,

For more than three hundred years, however much disagreement there may have been about the objectives of colonization or about the ways of governing colonies, there was complete agreement that a colony was a plantation of men, a place to which men emigrated and settled. Colon in French, Siedler in German, make the same point. (171) 
The idea of travel as a means of exploration and colonial enterprise is underlined by Bauer as in the following:

Anxiously conscious of the casual connections between Spain's soaring political might in Europe and Spanish possessions, late sixteenth century and early seventeenth century English promoters of exploration and empire invested substantial intellectual energies not only in encouraging Englishmen to engage in the colonial enterprise but also to make English explorations, hitherto conducted mainly in the form of 'privateering1', more useful to the nation at large. As a consequence, the period from 1580 s to the 1620 s saw a proliferation of manuals aimed at prescribing, formalizing, and regularizing the content and style of travel histories by urging travellers to adopt a more systematic stance when reporting on their voyages, by placing less emphasis on their own personal actions and more on geographically or ethnographically useful information. (138-9)

As mentioned before, works or 'manuals' were written by people who had travelled foreign countries and for people who intended to travel abroad. In such writings the main purpose of Englishmen was obtaining knowledge which was useful for 'political' strategies of the kingdom. For instance, even as early as 1575, Jerome Turler, in his The Traveiler, (with its original spelling) presented his recommendations for travellers of foreign countries:

The lande what maner one it is, and ... the people that dwell therin, whether thy bee stronge or weake, many or fewe, the Lande good or bad; what Cyties there bee, walled or not walled; the soyle fertile or barreine; wooddie or champion; so That there bee five principle poyntes too bee considered in euerie Cuntrey: the fame, figure, bignesse, jurisdiction, and situation. (50)

\footnotetext{
${ }^{1}$ A ship privately owned and crewed but authorized by a government during wartime to attack and capture enemy vessels. (Internet II)
} 


\section{Early Intimations of English Colonialism in Literary Writings of the $17^{\text {th }}$ Century}

Colonial writing was not only popular in the factual writings of the seventeenth century, but it was also manifest in several literary texts highlighting the political issues of contemporary England. It is undeniable that several literary writers in that era dealt with political subjects as they could not stay ignorant to political affairs. To put it differently, writers used their works as a vehicle to explore contemporary political problems. In this respect, colonial literature became another platform in which political ideas were developed when it was difficult for it to flourish elsewhere.

In such texts, what will be underlined in this sense is writers' preference of setting their stories in a distant land and a distant time. The answer to the question of why writers used foreign settings in their works is that they tried to establish their texts as a more overt means of political reflection. The contemporary political issue was mainly the expanding the boundaries of the kingdom and settling in foreign countries, which is now called the idea of colonialism. This idea "owes much to the example of Thomas More's Utopia, and that work's use of travel writing, set in Europe or the Americas, to combine political reflection and fiction." (Hadfield 136) In their works, Shakespeare, Fletcher and Behn experimented with a number of different forms of colonialism by combining historical and literary subjects.

\section{Colonialism in William Shakespeare's Two Plays}

\section{1) Othello or The Moor of Venice (1603):}

For this study, the play Othello is chosen to exemplify the colonial issues of England because the issues of race and 'colonial difference' were central to the English culture of the seventeenth century. As Loomba argues, "Shakespeare's plays have been an extraordinarily powerful medium between generations and cultures, a conduit for transmitting and shaping ideas about colonialism." (5) Therefore, because of its setting, and Othello's ethnic origin, the text of the play 
can be read as a manifest of colonialism. Briefly, the issues of Othello's 'outsideness' and political implications of colonialism in the play will be underlined in this part.

Shakespeare's tragedy Othello is believed to be based on the Italian short story "Un Capitano Moro" ("A Moorish Captain") by Cinthio, a disciple of Boccaccio, first published in 1565. Cinthio's Gli Hecatommithi (1565) is a collection of one hundred tales in the style of Boccacio's Decameron. No English translation of Cinthio was available in Shakespeare's lifetime, and verbal echoes in Othello are closer to the Italian original than to Gabriel Chappuy's 1584 French translation. Cinthio's tale may have been based on an actual incident occurring in Venice about 1508. It also resembles an incident described in the earlier tale of "The Three Apples", one of the stories narrated in the One Thousand and One Nights (Arabian Nights). (Internet 3)

For the plot of the play, it can be argued that it revolves around the fragile issue of individual and national identities. Although many Shakespearean critics disagree on Othello the character's skin colour and the play's meaning, Othello is taken as a text which raises such racial and colonial questions.

The questions of identity and difference became especially urgent in sixteenth and seventeenth-century English culture because at this time, as Helgerson argues, "the idea of an English nation developed and was articulated through a variety of media such as literature, law, cartography, or travel writing". (146) In Shakespeare's lifetime, especially Richard Hakluyt's great collection of voyages, Principal Navigations (1589) was available and included some 'outlandish' stories about other men (in Othello's words) “whose heads/ Do grow beneath their shoulders" (Othello I.III. 145-6) Furthermore, Loomba also suggests that

in the early modern period, Englishness was defined, in part, in opposition to everything not English... the idea of difference is important in complicating our understanding of the emergence of an English nation 
and in showing to what extent this was the result of an ongoing struggle to colonize, marginalize, or incorporate different groups of people who lived both within and outside the geographic boundaries of England. (2001: 149)

Othello is a Moor: "a dark-skinned, Arabian or African general" (Bevington 1151) who lives in a European, colour-prejudiced society, where he holds the rank of general in the Venetian military. Having a Moor character in the plays of the seventeenth century was something usual. As Loomba states, "Some scholars suggest that blackness was viewed as the ultimate sign of degradation, while other argue that it began to be viewed negatively only later, as a result of colonial domination of Africans." (2) However, as Hankey suggests being a Moor may mean other things:

Most stage Moors were devils, and their colour proclaimed them so. As G. K Hunter's essay "Othello and Colour Prejudice" has shown, in religious literature, in the medieval romances, in pictorial tradition, in mummer's plays, masques and processions, all the devils, infidels, Saracens, Turks, pagans and bogeymen, were black. The fact that there were white villains as well did not detract from the force of blackness as a symbol... The meaning of Moor is in fact 'Mahomedan', and terminology was so vogue at the time that, in use, 'Moor' meant no more than someone living in 'that outer circuit of non-Christian lands where the saving grace of Jerusalem is weakest in its whitening power. (10)

It can be said that the colour prejudice was prevalent at the time Shakespeare was writing Othello. After it is revealed that beautiful Desdemona elopes with Othello, her father angrily accuses him of casting a magic spell on his daughter that 'seemingly' underlines Othello's exotic oddness:

BRABANTIO:

0 thou foul thief, where hast thou stow'd my daughter?

Damn'd as thou art, thou hast enchanted her; 
For I'll refer me to all things of sense,

If she in chains of magic were not bound,

Whether a maid so tender, fair, and happy,

So opposite to marriage that she shunn'd

The wealthy curlèd darlings of our nation,

Would ever have, to incur a general mock,

Run from her guardage to the sooty bosom

Of such a thing as thou,- - to fear, not to delight.

Judge me the world, if 'tis not gross in sense

That thou hast practis'd on her with foul charms;

Abus'd her delicate youth with drugs or minerals

That weaken motion:-I'll have't disputed on;

'Tis probable, and palpable to thinking.

I therefore apprehend and do attach thee

For an abuser of the world, a practiser

Of arts inhibited and out of warrant.-

Lay hold upon him: if he do resist,

Subdue him at his peril. (I. II. 60-80)

Othello is an outsider in that he is feared and despised by his detractors including Iago, Brabantio, Duke, and etc., and he is disparagingly referred as the "thick lips" (I.I. 67), with a "sooty bosom". (I. II. 68) However, his 'oddness' attracts Desdemona as Othello also confesses:

OTHELLO:

Her father lov'd me; oft invited me;

Still question'd me the story of my life,

From year to year,- the battles, sieges, fortunes,

That I have pass'd.

I ran it through, even from my boyish days 
To the very moment that he bade me tell it:

Wherein I spake of most disastrous chances,

Of moving accidents by flood and field;

Of hair-breadth scapes I' the imminent deadly breach;

Of being taken by the insolent foe,

And sold to slavery; of my redemption thence,

And portance in my travels' history:

Wherein of antres vast and deserts idle,

Rough quarries, rocks, and hills whose heads touch heaven,

It was my hint to speak,- - such was the process;

And of the Cannibals that each other eat,

The Anthropophagi, and men whose heads

Do grow beneath their shoulders. This to hear

Would Desdemona seriously incline:

But still the house affairs would draw her thence;

Which ever as she could with haste despatch,

She'd come again, and with a greedy ear

Devour up my discourse; which I observing,

Took once a pliant hour; and found good means

To draw from her a prayer of earnest heart

That I would all my pilgrimage dilate,

Whereof by parcels she had something heard,

But not intentively; I did consent;

And often did beguile her of her tears,

When I did speak of some distressful stroke

That my youth suffer'd. My story being done,

She gave me for my pains a world of sighs:

She swore,-in faith, 'twas strange, 'twas passing strange;

'Twas pitiful, 'twas wondrous pitiful:

She wish'd she had not heard it, yet she wish'd 
That heaven had made her such a man: she thank'd me;

And bade me, if I had a friend that lov'd her,

I should but teach him how to tell my story,

And that would woo her. Upon this hint I spake:

She lov'd me for the dangers I had pass'd;

And I lov'd her that she did pity them.

This only is the witchcraft I have us'd:- (I. III. 129-69)

Furthermore, although Othello is regarded as a man outside the Christian fold, "the Venetian Senate responds in a mild way to the inter-racial marriage because Othello is so important to Venice in meeting the Turkish threat in Cyprus." (Loomba 2001: 159) When the country's interest is concerned, political issues become more important than every other thing. Therefore, Othello and Desdemona's marriage is 'mildly' accepted by authorities. Shakespeare successfully displays the idea that although Othello will remain as one of the outsiders within the society, when the colony of Italy, Cyprus, is threatened by the Ottomans, Othello is, nevertheless, needed as an important soldier to meet Turkish danger in Cyprus. As Loomba also suggests,

The English attitude to outsiders was not uniformly one of smug superiority. Europeans viewed Turks (to take but one example) with a great deal of anxiety as well as a grudging admiration of their military strength and organisation... As successful imperialists, The Turks were regarded as cruel and bloodthirsty, 'the scourge of Europe', but they were also overtly admired. England tried to establish trading connections with Morocco and other Islamic territories. (2001: 159)

Othello is not simply an alien who crosses over by marrying Desdemona, he is also the exotic outsider who alone is capable of defending Venice against other outsiders such as Turks. (2001: 162)

In the play it is also reflected as in the following words of the first senator:

We must not think the Turk is so unskilful

To leave that latest which concerns him first; 
Neglecting an attempt of ease and gain,

To wake and wage a danger profitless. (I.III. 27-30)

One can easily draw a parallelism between the binary of 'Othello and Iago' and the other binary 'Cyprus and Venice' within a colonial context. In other words, Othello may be read as a representative of the weak colonised Cyprus and Iago as the cynical and 'powerful' coloniser Venice. "Like Cyprus, Othello can be colonised by Venice - he can be put to use. But he can never become wholly Venetian." (Vaughan 21) For instance, Othello's own words about himself reveal his inferiority complex as he sees himself through others' eyes. In spite of being a general, he considers himself 'a weak subject':

OTHELLO:

Most potent, grave, and reverend signiors, My very noble and approv'd good masters,That I have ta'en away this old man's daughter, It is most true; true, I have married her: The very head and front of my offending Hath this extent, no more. Rude am I in my speech, And little bless'd with the soft phrase of peace; For since these arms of mine had seven years' pith, Till now some nine moons wasted, they have us'd Their dearest action in the tented field; And little of this great world can I speak, More than pertains to feats of broil and battle; And therefore little shall I grace my cause In speaking for myself. (I.III.78-96)

Iago is, on the other hand, a man whose head is filled with intrigues and cunning. He despises, hates Othello, and envies him. Like many people who have the inferiority complex, Iago tries to appear superior to Othello to conceal his inferiority. He plots against Othello as it is clearly seen in the following quotation: 
IAGO:

In following him, I follow but myself;

Heaven is my judge, not I for love and duty,

But seeming so for my peculiar end:

For when my outward action doth demonstrate

The native act and figure of my heart

In complement extern, 'tis not long after

But I will wear my heart upon my sleeve

For daws to peck at: I am not what I am. (I.I. 57-65)

Othello is regarded as the good character, but at the same time he has some flaws which eventually bring about his fall and tragic end. Othello's being an outsider "makes him vulnerable to Iago's wiles and, like Cyprus, if he is not fortified, he will turn Turk." (Vaughan 21) As a colonised, Othello cannot survive under the pressure of the 'powerful.' The binary opposition between two poles renders one (Venice/Iago) powerful and the other (Cyprus/Othello) weak. However, as a coloniser, the 'evil' but powerful character, Iago survives at the end of the play, while Othello dies.

In Homi Bhabba's terms Othello is a "mimic man" (125) who desperately wants to become absorbed into his adopted society, but always exposed by his irreclaimably alien characteristics. He is simply "almost the same but not quite." (123)

Vaughan carries her argument further by arguing that "on a mythic level the conflict between Venice and Ottoman Empire was Manichaean, symbolic of the universal struggle between the forces of good and evil." (27) In this sense, whatever Othello does to make himself into, he serves as a reminder to the people of Venice that "he is a dangerous figure inhabiting the boundary between their civilisation and the barbarism of others." (Hadfield 229)

One can outline multiple colonial contexts of Othello. As another point, the setting(s) of the play can be taken into consideration as geographical locations of 
the play are interesting and contradictory. Shakespeare moves the play from Venice to Cyprus in order to have a liberty to talk about the colonial activities of England. At this point, it can be suggested that another binary opposition emerges, which is between Venice and Cyprus as representatives of England and Ireland. According to Hadfield, Othello can be read as "an allegory of contemporary England struggling against the dangers of savage Ireland." (201) As Hadfield argues,

Othello, a play which represents the ideal republic of Venice as the last bastion of European civilisation pitted against the lure and danger of the barbarous and exotic Orient, but which can also be read as an allegory of contemporary England struggling against the dangers of savage Ireland. (201)

Moreover, as Vaughan maintains,

In the opening scenes of Othello the virtuous commonwealth is threatened by the barbarous Turk... Venice seems sure of its identity as the play begins urbane and civilised; as Brabantio exclaims, 'This is Venice;/ My house is not a grange.' (I.I. 105-06) Centuries of legal and governmental tradition have defined Venice as the locus of rational judgement... (21)

In one of the early scenes of the play, it is revealed that Duke assigns Othello with a duty which is defending Cyprus, a Venetian colony, against the enemy, Ottoman. Cyprus represents, in Vaughan's words, "a liminal zone between Venice's Christian civility and the Ottomite's pagan barbarism ... Cyprus is the frontier, the uttermost edge of Western civilisation, simultaneously vulnerable to attack from without and subversion from within." (22) "Othello expresses exactly the contemporary fears the English had of Ireland as a colonial space and the Irish as a colonised people." (Hadfield 229)

Ireland is repeatedly mentioned in many plays of Shakespeare such as in The Comedy of Errors, Richard III, and Henry IV. As Hadfield claims, "English 
writers traditionally regarded Ireland as a dangerous colonial space, a land where they were likely to lose their identity and 'degenerate' by going native." (Hadfield 231) If Ireland is regarded as a country which is dangerous for English who move there as they might lose their sense of home left behind, in the play Cyprus is depicted in the same manner like Ireland. If one reads Cyprus as analogous to Ireland, Venice then should be read as England. Italy is a setting that in Shakespeare's plays both reflects, and offers a contrast to, the audience's England. As Loomba also asserts, “Italians are 'Southern' like the Asians, different from the English, but when placed against the Moors, they are a part of Christian Europe." (94) However, Hadfield claims that "Venice cannot be read as a straightforward representation of England... it functions, yet again, as an ideal to which England might aspire..." (241) Venice in Othello is depicted as a society which is liberal enough to tolerate the black outsiders. Moreover, the council meeting scene also underlines the democratic nature of Venetian government as matters of public importance are discussed openly and both Othello and Desdemona are granted a right to conduct a proper defence of their actions in front of the Duke. However, what Cyprus lacks is in existence in Venice. It is constantly represented in contrast to the motherland. While there is liberty, order and individual rights in Venice, there is rumour, slander and violence in Cyprus.

Briefly, Shakespeare's play Othello does not only carry colonial implications but it also warns English politicians and court men about the sensitivity of colonial issues. As Hadfield puts it forward, "The play serves as a warning to England, of the havoc which an uncontrolled colony like Ireland could wreak to the certainties of a (supposedly) established, civilised identity." (241)

\section{2) The Tempest (1610-11):}

The Tempest is another play, a romance, by Shakespeare in which political implications of English colonial actions can be traced. It is an important play in the ways it reflects the relationship between European and colonial politics. As Hadfield argues, "the play demonstrates an acute awareness of the interaction 
and overlap between domestic and colonial politics." (243) In this part of the study, the setting of the play will be considered in the context of the English politics, and the power relations between the dominant and the other, will be highlighted.

The play is set in exotic Mediterranean territories. The island where the reader finds Prospero is somewhere off the coast of Africa, "probably in the region of Algeria or Tunisia," (Hadfield 243) as Gonzalo indicates, "Methinks our garments are now as fresh as when/ we put them on first in Afric, at the marriage of the/ King's fair daughter Claribel to the King of Tunis." II.I. 66-8) However, Gillies points out,

Shakespeare's play is vitally rather than casually implicated in the discourses of American and the Virginia colony because of its participation within the contemporary debates about colonialism which were inevitably centred on the English colonies in the New World. (149)

It can be argued that the play revolves around 'an intrigue of dynastic politics' because the rightful Duke of Milan, Prospero (and a sorcerer) is tricked by his ambitious younger brother, Antonio, and Prospero and his three-year-old daughter, Miranda have to live on an island where they meet Caliban (the son of a witch called Sycorax) asserts that "This island's mine." (I.II. 332) As Wilson alleges, the play is about the governmental problems that "Europeans encountered when dealing with peoples from other continents, whether as trading partners or inferiors whose lands were to be colonised." (334-6)

Caliban is the representative of 'uncivilised' man. When 'civilised' Prospero and Miranda first came to the island, they started to construct a threatening 'other' which is Caliban. The rightful owner of the island is made an outsider by Prospero:

CALIBAN:

This island's mine, by Sycorax my mother, 
Which thou tak'st from me. When thou cam'st first,

Thou strok'st me and made much of me, wouldst give me

Water with berries in't, and teach me how

To name the bigger light, and how the less,

That burn by day and night; and then I lov'd thee,

And show'd thee all the qualities o' th' isle,

The fresh springs, brine-pits, barren place and fertile.

Curs'd be I that did so! All the charms

Of Sycorax, toads, beetles, bats, light on you!

For I am all the subjects that you have,

Which first was mine own king; and here you sty me

In this hard rock, whiles you do keep from me

The rest o' th' island.

Caliban is angry because Prospero, a man of authority from the Old World, took everything Caliban, a man from the New World, once had; and Prospero transform Caliban into 'a subject or a slave' in his (Prospero's) 'kingdom'. As Skura asserts, "Caliban is the centre of the play because Europeans were at that time exploiting the real Calibans of the world, and The Tempest was part of the process." (44)

It can be argued that when Shakespeare was writing The Tempest, he included a lot of information that corresponded with the travels' reports from the New World. As Kermode states,

reports of a particular episode in British efforts to colonise North America had participated the play's major themes. In 1609 nine ships had left England to settle the colony in Jamestown, Virginia, and the Sea Venture, carrying all of the colonial officers had disappeared. But its passengers reappeared in Virginia one year later, miraculously saved; they had wrecked off the Bermudas, until then believed demonically dangerous but now found to be providentially mild and fruitful. These events, much in the news in the year just 
preceding The Tempest have long been seen as a relevant context for the play by all... (xxv)

Furthermore, Strach[e]y asserts that "Samuel Purchas asked 'Can a Leopard change his spots? Can a Savage remayning a Savage be civill?' Purchas added this comment when he published the 1610 document that Shakespeare had used as his source for The Tempest, and Purchas has been cited as an example of colonialist discourse." (62)

Various distortions were discursive strategies that served the political purpose of making the New World fit into a schema justifying colonialism." (Skura 45) Prospero is a Duke who is a representative of England's colonising, especially her (England's) will to raise savage peoples from superstitions, taboos and witchcraft to a more enlightened existence. Therefore, on the island, Prospero secured this status by teaching Caliban his own language and religion because Prospero regards Caliban as "a salvage and deformed slave" (1135) as it is stated in the beginning of the play. Caliban is always despised and hated by Prospero and Miranda as he once attempts to rape Miranda. His "bestial lust" is affirmed by this action, and Prospero justifies and rationalizes his acts, his tyranny:

\section{PROSPERO:}

Thou most lying slave,

Whom stripes may move, not kindness! I have us'd thee,

Filth as thou art, with human care, and lodg'd thee

In mine own cell, till thou didst seek to violate

The honour of my child.

CALIBAN:

O ho, $\mathrm{O}$ ho! Would't had been done.

Thou didst prevent me; I had peopl'd else

This isle with Calibans.

MIRANDA: 
Abhorred slave,

Which any print of goodness wilt not take,

Being capable of all ill! I pitied thee,

Took pains to make thee speak, taught thee each hour

One thing or other. When thou didst not, savage,

Know thine own meaning, but wouldst gabble like

A thing most brutish, I endow'd thy purposes

With words that made them known. But thy vile race,

Though thou didst learn, had that in't which good natures

Could not abide to be with; therefore wast thou

Deservedly confin'd into this rock, who hadst

Deserv'd more than a prison.

CALIBAN:

You taught me language, and my profit on't

Is, I know how to curse. The red plague rid you

For learning me your language!

PROSPERO:

Hag-seed, hence!

Fetch us in fuel. And be quick, thou 'rt best,

To answer other business. Shrug'st thou, malice?

If thou neglect'st, or dost unwillingly

What I command, I'll rack thee with old cramps,

Fill all thy bones with aches, make thee roar,

That beasts shall tremble at thy din.

CALIBAN:

No, pray thee.

[Aside] I must obey. His art is of such pow'r,

It would control my dam's god, Setebos,

And make a vassal of him.

PROSPERO: 
So, slave; hence! ( I.II. 346-76)

Prospero thinks that he did a favour to Caliban by teaching him 'how to be civilised' and he expects to be respected in return for this favour. However, he thinks his 'goodness' is responded by 'badness' and 'ingratitude' as Caliban hates him and threatens his authority on the island. Viewed from this perspective, Caliban can be taken as a colonialist representation of the 'Other'. Moreover, as the quotation above also signifies, Shakespeare lets a mistreated native (Caliban) complain onstage. In other words, Shakespeare depicts a native from the inside.

Shakespeare uses the vocabulary and images of the New World or colonialist discourse (in modern sense) to describe something closer to home, England. Prospero is an exile politician who wants to take revenge on his enemies, Antonio (Prospero's brother, the Duke of Milan) and Alonso (the King of Naples). He solves his old problems on the island as he uses illegitimate power on others. Although he is powerful on the island, he is not satisfied with it. He uses the relationship between Miranda and Ferdinand (Alonso's son) to ensure his return to power in Milan. As Skura also indicates, "When The Tempest was written, what the New World seems to have meant for the majority of Englishmen was a sense of possibility and a set of conflicting fantasies about the wonders to be found there; these were perhaps the preconditions for colonialism." (57) In this sense, Prospero finds 'a second-chance' on an island, as at the end of the play Miranda puts, "in a brave new world", (V.I. 81) not in Italy, Milan:

MIRANDA:

0, wonder!

How many goodly creatures are there here!

How beauteous mankind is! 0 brave new world

That has such people in't!

PROSPERO:

'Tis new to thee.

ALONSO: 
What is this maid with whom thou wast at play?

Your eld'st acquaintance cannot be three hours;

Is she the goddess that hath sever'd us,

And brought us thus together?

FERDINAND:

Sir, she is mortal;

But by immortal Providence she's mine.

I chose her when I could not ask my father

For his advice, nor thought I had one. She

Is daughter to this famous Duke of Milan,

Of whom so often I have heard renown

But never saw before; of whom I have

Receiv'd a second life; and second father

This lady makes him to me.

ALONSO:

I am hers.

But, $\mathrm{O}$, how oddly will it sound that I

Must ask my child forgiveness!

PROSPERO:

There, sir, stop;

Let us not burden our remembrances with

A heaviness that's gone.

GONZALO:

I have inly wept,

Or should have spoke ere this. Look down, you gods,

And on this couple drop a blessed crown;

For it is you that have chalk'd forth the way

Which brought us hither. 


\section{Colonialism in John Fletcher's late Jacobean Tragicomedy}

The Island Princess (1619-22):

The Island Princess is a complicated and intriguing play which is "much more directly concerned with England's colonial experience in the reign of James I than The Tempest." (Hadfield 254) The play is important as it displays two different perspectives of colonisers (Europeans) towards exotic peoples. The play also demonstrates the importance of religion in the colonialist discourse.

Unlike The Tempest, Fletcher's play has a very definite location. The action is set on the Moluccan island of Tidore which is a colony of Portugal. Tidore is a multicultural place with its native islanders and the Portuguese people.

The events start with the evil Governor of Ternata's kidnapping the king of Tidore. The king's beautiful sister, Quisara, is Tidore's princess around whom the story centres. Quisara has many suitors, but she is in love with a 'Portuguese' sailor, Ruy Dias. However, she announces that she will marry whoever rescues her brother, expecting the hero to be her lover, Ruy Dias. The early signals of an inter-racial marriage are displayed at the beginning of the play, and so a parallelism can be inferred between this one and the inter-racial marriage between Othello and Desdemona. This sort of marriage is often presented in the colonial writings of the era because an inter-racial marriage can be taken as a sort of treaty between 'us' and 'they', and as a kind of 'link' to guarantee the supremacy of the dominant. Besides, Quisara is not an ordinary native girl; she is the princess, an important political figure, so this is also an important factor in the quest for power in the eyes of colonisers. Therefore, it can be argued that marriage is used as a strategy to convert and assimilate the other.

Quisara is disappointed by her lover due to his failure because a stranger (but again a Portuguese) man called Armusia manages to rescue her brother the king, not Ruy Dias. Armusia's success in rescuing the king is achieved via the use of a barrel of gunpowder. This seems to be a detail in the plot. However, it is not 
insignificant because 'the use of gunpowder in the fight' is an indication of superiority of Europeans over the natives whose technology is inadequate. The cries of citizens also reveal their fear when they confront this man-originated danger and attack:

Citizens:

Fire, fire!

Government:

Where? where?

Citizens:

Suddenly taken in a merchant's house,

Fearful and bigh it blazes.

Help, good people!

Government:

Pox o' their paper-houses!

How they smother!

They light like candles!

How the roar still rises! (II.II pg. 126)

After that incident, the two Portuguese men fight a duel for the princess, and Ruy Dias is defeated by Armusia once more. Ruy Dias begins to respect Armusia and decides to leave Quisara and him alone. Furthermore, the evil Governor is full of hatred to both Portuguese men, and so disguises himself as a priest to turn the people of Tidore against the Portuguese. Therefore, Quisara demands Armusia to convert to her religion, a primitive form of sun-moonworship. However, Armusia refuses to convert from Christianity to her religion. At the end of the play, the disguised Governor is exposed and Armusia and the 
princess reunite, symbolizing the reconciliation between the Portuguese and islanders.

When one reads between the lines of the play, s/he will discover some other dimensions concerning colonial issues. In the play two extremely opposing states of European reaction to the exotic are obviously reinforced; it is their oscillation between fear and fascination evoked by the Other. One of the reactions is the unquenchable 'wonder or fascination' that attracts them to natives and the other is the vicious 'hostility or fear' towards the islanders.

The Portuguese come to the island with great expectations and out of curiosity. They are so curious about the unknown or undiscovered things on the island. The concept 'wonder', which is enforced by 'the will to power', drives them and fills their heart with excitement as it is manifest in Armusia's words below:

We are arriv'd among the blessed Islands,

Where every wind that rises blowes perfumes,

And every breath of aire is like an Incense:

That treasure of the Sun dwels here, each tree

As if it envied the old Paradice,

Strives to bring forth immortal fruit; the spices

Renewing nature...

Nothing we see, but breeds an admiration;

The bowels of the earth swell with the births

Of thousand unknowne gems, and thousand riches;

Nothing that bears a life, but brings a treasure;

The people they shew brave too, civill manner'd, Proportioned like the Mastres of great minds, The women which I wonder at- (I.III. pg 99)

Although Europeans are driven by their excitement and admiration for the exotic, Fletcher, at the same time, mentions Europeans' enmity that results in a 
feeling of 'fear' in the hearts of colonials who are still subjects to the mother country: they are afraid of the possibility of the conversion from Christianity into barbarian religions rather than vice versa. As Hadfield also underlines, "When the Governor of Ternate seeks to turn Quisara against the Portuguese he uses his bogus identity as a holy man to suggest that religion is the key to future oppression and invasion." (256) The Governor urges Quisara to use her beauty to convince Europeans to transform to their religion, and he thinks she should use her physical gift for the advantage of her own people, not for Europeans:

Use it discreetly,

For I perceive ye understand me rightly,

For here the gods regard your helpe, and suddenly;

The Portugals like sharpe thornes (marke me Lady)

Sticke in our sides; like razors, wound religion,

Draw deep, they wound, till the life bloud followes,

Our gods they spurne at, and their worships scorne,

A mighty hand they beare upon our government.

These are the men your miracle must worke on,

Your heavenly forme, either to roote them out...

Or fairely bring 'em home to our devotions [.] (IV.II. pg. 119)

The Governor suggests that if Quisara persuades Armusia to convert into their religion, she could set an example for Europeans, and the Portuguese would follow Armusia's conversion. Armusia is a calm and balanced man, but "when Quisara attempts to convert him to the nature-religion of the islanders under the watchful eye of the scheming Governor of Ternata, he reveals the disgust rather than the wonder of European perceptions of exotic people." (my emphasis, Hadfield 259) When Quisara implores Armusia to offer a sacrifice to her gods, he clearly discloses his 'hidden' disgust as in the following:

To the Devill, Lady? 
Offer to him I hate? I know the devill;

To dogs and cats? you make offer to them;

To every bird that flies, and every worme.

How terribly I shake! Is this the venture?

The tryall that tou talkt off? where have I bin?

And how forgot my selfe? how lost my memorie?

When did I pray or looke up stedfastly?

Had any goodnesse in my heart to guide me?

That I should give this vantage to mine enemie,

The enemie to my peace; forsake my faith? (IV. V. pg. 122)

Hadfield interprets this quotation that, "In representing the religion of the natives as devil worship, and in expressing the fear that cultural traffic will flow the wrong way, Armusia is rehearsing widely held beliefs which were common currency of the discourse of contemporary colonialism." (259) It is not only Armusia who hates the natives, but another Portuguese man, Pynerio also reveals his hatred; "Thinke some abominable names - are they not Devils? / But the devil's a great deale too good for 'em'. (V.I. pg. 124)

In Fletcher's play the Portuguese can be read as the representatives of the English because the location he uses as the setting of the play, the Moluccan islands in the Bay of Bengal, was considerably important for English imperial and trading interests in the second decade of James's reign.

There were a number of well-publicised voyages to the East Indies and Japan in this decade, one of which, John Saris's account of his voyage to Japan, had been included in... the editions of Samuel Purchas's... collection of English voyages... Saris's voyage contains the description of an incident which bears some resemblance to the description of the conflict between the two islands as represented in The Island Princess... given the topical importance of the location of The Island Princess, it seems likely that there is some 
relation between these details of Saris's experience in Tidor and Fletcher's play, the former probably providing the basis for the story of the king of Tidore's kidnap when out rowing (I.I. 28) and the explosion which helps to rescue him. This would suggest that Fletcher' eye was on documents of English voyages abroad, that his play was designed as a reflection on contemporary English colonization and trade, and that the Portuguese can be read as English, a dramatic convention which stretched back into the second half of the previous monarch's reign. (Hadfield 261-2)

The Island Princess is a play which deals with Europeans' desire of colonial expansion, and it is about their anxieties about the unknown. Then the play reinforces the idea that 'what is unknown is both threatening and alluring.' In the play it is not only Europeans who think the islanders are threatening, the natives of Tidore also regard the colonisers as threatening and domineering. In other words, "Fletcher... suggest[s] that ill-considered projects would lead only to a self-perpetuating cycle whereby European and non-European cultures would view each other with mutual suspicion." (Hadfield 263) At the end of the play, the Portuguese man Armusia persuades Quisara to convert to Christianity: "Your faith, and your religion must be like ye, / They that can shew you these, must be pure mirrours; / When the streames flow cleare and faire, what are the fountaines? (V.I. pg. 126) Moreover, the king of Tidore also confesses to Armusia that his noble example has "halfe perswaded me to be a Christian" (V.V. pg. 128) The play ends with the victory of Europeans as Quisara and her brother seem to embrace the colonisers' religion, Christianity, and the powerful and superior Europeans' authority is eventually fortified once more.

\section{Colonialism in Aphra Behn's Fiction}

\section{Oroonoko: or, the Royal Slave. A True Story (1688):}

Aphra Behn in her prose narrative which "cannot be classified as fact or fiction, realism or romance" (The Norton Anthology 1865) tells the story of an 
African prince who becomes a slave. A seventeenth century novel, Oroonoko is an important work both because it is one of the earliest English novels and because it is clearly and directly related with the early colonial pursuits of England. As Azim claims "It is read not only as the first novel to be written by a woman, but also as the first 'emancipation' novel, dealing in detail with the misery and plight of Black slaves." (43) In this part of the study, the reading of Oroonoko will concentrate on the status of the Black man, Oroonoko, and the manner of his entry into the field of representation as 'an object of examination'.

Oroonoko, which is written by a white female author using a white female narrative voice, sets itself up as a celebration of a particular Black slave. As Azim also states "Oroonoko stands witness to and is part of the imperial project, as its initial admiration for its Black subject proves to be flirtatious and frivolous." (45)

I Do not pretend, in giving you the History of this ROYAL $S L A V E$, to entertain my Reader with the Adventures of a feign'd Hero, whose Life and Fortunes Fancy may manage at the Poet's Pleasure; nor in relating the Truth, design to adorn it with any Accidents, but such as arrived in earnest to him: And it shall come simply into the World, recommended by its own proper Merits, and natural Intrigues; there being enough of Reality to support it, and to render it diverting, without the Addition of Invention. (129)

The narrator of the novel is sometimes inscribed directly into the story along with the hero. However, in some parts she and Oroonoko both having their own reasons part ways. To show their experiences and accounts the novel can be divided into three parts according to levels of narration. The first part of the novel is Oroonoko's life in Africa of which the narrator does not have any firsthand experience. The first part of the novel is narrated to her as it is understood by the use of such phrases as

I have often heard him say, had certainly kill'd him, but for the Conversation of this Prince and Aboan, and the French Governor he had from his Childhood, of whom I have spoken before, and who was a Man of admirable 
Wit, great Ingenuity and Learning; all which he had infused into his young Pupil. (my emphasis, 159-60)

Africa is Oroonoko's natural habitat. The narrator sounds like an observer or a reporter who wants to appear as impartial and adjudging in order to show Africa and its inhabitants as objects of curiosity 'under western eyes'.

The beginning of the text is also worth mentioning in some detail. The narrator starts describing Surinam, an English colony in the West Indies; its flora and fauna, its inhabitants, their traditions and its potential for commercial. Moreover, she clearly differentiates natives of Surinam from the slaves brought from Africa as there are three communities there; Indians, slaves and colonisers:

But before I give you the Story of this Gallant Slave, 'tis fit I tell you the Manner of bringing them to these new Colonies; those they make Use of there, not being Natives of the Place: for those we live with in perfect Amity, without daring to command 'em; but, on the contrary, caress 'em with all the brotherly and friendly Affection in the World; trading with them for their Fish, Venison, Buffaloes Skins, and little Rarities; as Marmosets, a sort of Monkey, as big as a Rat or Weasel, but of a marvellous and delicate Shape, having Face and Hands like a Human Creature; and Cousheries, a little Beast in the Form and Fashion of a Lion, as big as a Kitten, but so exactly made in all Parts like that Noble Beast, that it is it in Miniature: Then for little Paraketoes, great Parrots, Muckaws, and a thousand other Birds and Beasts of wonderful and surprizing Forms, Shapes, and Colours: For Skins of prodigious Snakes, of which there are some three-score Yards in Length; as is the Skin of one that may be seen at his Majesty's Antiquary's; where are also some rare Flies, of amazing Forms and Colours, presented to 'em by myself; some as big as my Fist, some less; and all of various Excellencies, such as Art cannot imitate. Then we trade for Feathers, which they order into all Shapes, make themselves little short Habits of 'em, and glorious Wreaths for their Heads, Necks, Arms and Legs, whose Tinctures are unconceivable... We dealt with 'em with Beads of all Colours, Knives, Axes, Pins and Needles, which they us'd 
only as Tools to drill Holes with in their Ears, Noses and Lips, where they hang a great many little Things; as long Beads, Bits of Tin, Brass or Silver beat thin, and any shining Trinket. The Beads they weave into Aprons about a Quarter of an Ell long, and of the same Breadth; working them very prettily in Flowers of several Colours; which Apron they wear just before 'em, as Adam and Eve did the Fig-leaves; the Men wearing a long Stripe of Linen, which they deal with us for. They thread these Beads also on long Cotton-threads, and make Girdles to tie their Aprons to, which come twenty times, or more, about the Waste, and then cross, like a Shoulder-belt, both Ways, and round their Necks, Arms and Legs. This Adornment, with their long black Hair, and the Face painted in little Specks or Flowers here and there, makes 'em a wonderful Figure to behold. Some of the Beauties, which indeed are finely shap'd, as almost all are, and who have pretty Features, are charming and novel; for they have all that is called Beauty, except the Colour, which is a reddish Yellow; or after a new Oiling, which they often use to themselves, they are of the Colour of a new Brick, but smooth, soft and sleek. They are extreme modest and bashful, very shy, and nice of being touch'd. And tho' they are all thus naked, if one lives for ever among 'em, there is not to be seen an indecent Action, or Glance: and being continually us'd to see one another so unadorn'd, so like our first Parents before the Fall, it seems as if they had no Wishes, there being nothing to heighten Curiosity: but all you can see, you see at once, and every Moment see; and where there is no Novelty, there can be no Curiosity. Not but I have seen a handsome young Indian, dying for Love of a very beautiful young Indian Maid; but all his Courtship was, to fold his Arms, pursue her with his Eyes, and Sighs were all his Language: While she, as if no such Lover were present, or rather as if she desired none such, carefully guarded her Eyes from beholding him; and never approach'd him, but she looked down with all the blushing Modesty I have seen in the most Severe and Cautious of our World. And these People represented to me an absolute Idea of the first State of Innocence, before Man knew how to sin: And 'tis most evident and plain, that simple Nature is the most harmless, inoffensive and virtuous Mistress. 'Tis she alone, if she were permitted, that better 
instructs the World, than all the Inventions of Man: Religion would here but destroy that Tranquillity they possess by Ignorance; and Laws would but teach 'em to know Offences, of which now they have no Notion. (130-2)

The European settlers trade with Indians who are portrayed as innocent, pure, beautiful and honest people. This description reminds one of the 'noble savage' idea. "The cult and notion of the 'noble savage' arose out a romantic disillusion with European civilisation and a search for innocence and authenticity." (Azim 40) Furthermore, although "'Tis a Continent, whose vast Extent was never yet known," (Oroonoko 179) and are regarded as dangerous, the known/colonised parts of Surinam are likened to a tropical heaven:

Groves of Oranges, Lemons, Citrons, Figs, Nutmegs, and noble Aromaticks, continually bearing their Fragrancies: The Trees appearing all like Nosegays, adorn'd with Flowers of different Kinds; some are all White, some Purple, some Scarlet, some Blue, some Yellow; bearing at the same Time ripe Fruit, and blooming young, or producing every Day new. (178)

In this first part of the novel, it is stated that it is not only Europeans who become settlers in Surinam but slaves from another continent are also made settlers there. Like white Europeans, slaves also travel across the Atlantic to the new world. Slaves are generally brought from Coramantien to make them work in the plantations of sugar. As the narrator explains it,

Coramantien ${ }^{2}$, a Country of Blacks so called, was one of those Places in which they found the most advantageous Trading for these Slaves, and thither most of our great Traders in that Merchandize traffick; for that Nation is very warlike and brave; and having a continual Campaign, being always in Hostility with one neighbouring Prince or other, they had the Fortune to

\footnotetext{
${ }^{2}$ A British-held fort and slave market on the Gold Coast of Africa, in modern-day Ghana.
} 
take a great many Captives: for all they took in Battle were sold as Slaves; 134at least those common Men who could not ransom themselves. Of these Slaves so taken, the General only has all the Profit; and of these Generals our Captains and Masters of Ships buy all their Freights.

As Europeans admire the physical strength of African Black men, Oroonoko is brought forward as a handsome seventeen-year old grandson of the King of Coramantien. When the narrator meets Oroonoko for the first time, she cannot hide her surprise because of his difference:

He came into the Room, and addressed himself to me, and some other Women, with the best Grace in the World. He was pretty tall, but of a Shape the most exact that can be fancy'd: The most famous Statuary could not form the Figure of a Man more admirably turn'd from Head to Foot. His Face was not of that brown rusty Black which most of that Nation are, but a perfect Ebony, or polished Jet. His Eyes were the most aweful that could be seen, and very piercing; the White of 'em being like Snow, as were his Teeth. His Nose was rising and Roman, instead of African and flat: His Mouth the finest shaped that could be seen; far from those great turn'd Lips, which are so natural to the rest of the Negroes. The whole Proportion and Air of his Face was so nobly and exactly form'd, that bating his Colour, there could be nothing in Nature more beautiful, agreeable and handsome. There was no one Grace wanting, that bears the Standard of true Beauty. His Hair came down to his Shoulders, by the Aids of Art, which was by pulling it out with a Quill, and keeping it comb'd; of which he took particular Care. (136-7)

The narrator finds Oroonoko different from other 'Negros' because of his appearance and his royal blood. "The representation of Oroonoko is typical of accounts of the colonised subject, where that subject, divided and ruptured by the processes of colonial domination, is fetishised and held up to view as an object of investigation, sometimes fearful and at others desirable." (Azim 50) The black woman of the text is "fair Imoinda", (138) and love between Oroonoko and 
Imoinda is interrupted because of Oroonoko's grandfather' (the King's) lust for her. Although she is given the royal veil ${ }^{3}$ by the king, Oroonoko manages to enter her room with the help of Onahal and ravishes her in a moment. Therefore, Imoinda can be neither the queen nor Oroonoko's wife, so she is sold into slavery. Assuming that Imoinda is dead Oroonoko becomes very sad, but after a while he decides to resume his duty which is selling slaves to white merchants. However, after the fraud of a European captain Oroonoko is also sold into slavery and brought to Surinam like other slaves. [Oroonoko is] "this innocent and glorious Prize, who thought of nothing less than such an Entertainment." (162) Sold as a slave to a man called Trefry, Oroonoko who is baptised as Caesar in Surinam is now a royal slave. At this stage it can be argued that one of the statements of the narrator concerning the act of renaming is interesting: "For the future therefore I must call Oroonoko Caesar; since by that Name only he was known in our Western World." (169) The importance of this statement stems from the narrator's drawing a distinction between white men and black men. "Oroonoko's status in the colony is determined by the system of slavery." (Azim 55)

The second part of the text deals with the reunion of Imoinda and Oroonoko or with their new 'Christian' names Clemene and Caesar. This part of the novel praises the practice of slavery and England's colonial expansion. Behn as a royalist approves the Court's colonial activities as a means of civilising others while trading. "Behn was a lifelong and militant royalist, and her fictions are quite consistent in portraying virtuous royalists and put-upon nobles who are opposed by petty and evil republicans/Parliamentarians." (Internet) Furthermore, on this topic, as Azim highlights,

though there is a celebration of Other 'primitive' cultures, it is nonetheless the products of the European Enlightenment who are celebrated. Trefry stands as representative and symbol of the new order in Europe. However, the economic prosperity of that order is based on commercial and colonial expansion. (56)

\footnotetext{
${ }^{3}$ A symbol of invitation to the royal bed.
} 
Upon Imoinda's pregnancy, Oroonoko demands for their liberty and return to the home land. However, he is refused. Ironically enough, a text which claims itself to be interested in human rights legitimises a system that trade in human bodies. Therefore, the narrator and Oroonoko start to disagree about the concept of rights when especially Oroonoko has thoughts of escape and rebellion. "Her admiration for the hero is replaced by suspicion." (Azim 57) In this sense, the reader can draw a simple conclusion about Behn's thoughts about England's colonial expansion: she thinks that as long as Oroonoko remains within the conditions laid down by his white masters, he can be loved and admired. Therefore, towards the end of the text the friendly and admiring European narrator is shocked at Oroonoko's rebellion. His attempts of escape fade and they are caught and whipped. At the end of the novel, Oroonoko kills his wife and child to efface his future in an act of desperation. Oroonoko is tortured, publicly executed and his body is torn into pieces.

What Behn underlines in the colonial sense is the devastating experiences lived in a colony which is not ruled by 'a good governor' and she never protests against slavery. She always has faith in King and his decisions regarding colonialism. In a sense, Aphra Behn, like Bacon tries to show the 'proper ways of colonising' others, and she does it illustrating a bad-ruled colony, peopled with unlucky slaves such as Oroonoko and Imoinda.

Thus died this great Man, worthy of a better Fate, and a more sublime Wit than mine to write his Praise: Yet, I hope, the Reputation of my Pen is considerable enough to make his glorious Name to survive to all Ages, with that of the brave, the beautiful and the constant Imoinda.

Therefore, at the end of the novel Behn seems to be sorry for Oroonoko but her pity is just for one man. She does not criticise the whole system of colonization and slavery. 
Consequently, this paper has claimed that Shakespeare's, Fletcher's and Behn's colonial writings display a lot of contemporary political issues in England. Besides they are regarded as suitable materials to be interpreted in order to understand modern/post-colonialism with modern terminology. This study has also shown the importance of colonialism in the seventeenth century England to gain either 'power' or reinforce its 'supremacy' over other nations. 


\section{Works Cited}

Abrams, M. H. ed. The Norton Anthology of English Literature. $6^{\text {th }}$ Edition. London: Norton\&Company, 1993.

Azim, Firdous. The Colonial Rise of the Novel. London: Routledge, 1993.

Behn, Aphra. Oroonoko: or, The Royal Slave. A True Story in The Works of Aphra Behn. E-text from Project Gutenberg. http://www.gutenberg.org/files/29854/29854-h/29854-h.htm

Bevington, David. The Complete Works of Shakespeare. New York: Pearson, 2009.

Bauer, Ralph. "Travel, Exploration, and Empire" in English Renaissance Literature. ed. Donna B. Hamilton. Oxford: Blackwell Publishing, 2006.

Bhabba, Homi. The Location of Culture. New York: Routledge, 1994.

Bush, Douglas. English Literature in the Early Seventeenth Century, 16001660. Oxford: The Clarendon Press, 1952.

Finley, M. I. "Colonies: An Attempt at a Typology". Source: Transactions of the Royal Historical Society, Fifth Series, Vol. 26 (1976), pp. 167-188 Published by: Royal Historical Society Stable URL: http://www.jstor.org/stable/3679077

Fletcher, John. The Island Princess. ed. George Walton Williams, in The Dramatic Works in the Beaumont and Fletcher Canon. ed. Fredson Bowers. Cambridge: Cambridge University Press, 1982.

Foucault, Michel. "What is an Author?" in The Foucault Reader. ed. Paul Rabinow. Harmondsworth: Penguin, 1986. The History of Sexuality: An Introduction Vol. 1. New York: Vintage

Books. 1990.

Gillies, John. Shakespeare and the Geography of Difference. Cambridge: The Press Syndicate of the University of Cambridge, 1994.

Gordon, Colin. ed. Power/Knowledge: Selected Interviews \& Other Writings 1972-1977. New York: Pantheon Books, 1980. 
Hadfield, Andrew. Literature, Travel, and Colonial Writing in the English Renaissance 1545-1625. Oxford: Oxford University Press, 1998.

Hankey, Julie. ed Othello $2^{\text {nd }}$ Edition. Cambridge: Cambridge University Press, 2005.

Helgerson, Richard. Forms of Nationhood: The Elizabethan Writing of England. Chicago and London: University of Chicago Press, 1992.

Horvath, Ronal J. "A Definition of Colonialism" Source: Current Anthropology, Vol. 13, No. 1 (Feb., 1972), pp. 45-57 Published by: The University of Chicago Press on behalf of Wenner-Gren Foundation for Anthropological Research Stable URL: http://www.jstor.org/stable/2741072

Hunter G. K., "Othello and Colour Prejudice" in Dramatic Identities and Cultural Tradition: Studies in Shakespeare and His Contemporaries. Liverpool University Press, 1978.

Kermode, Frank. The Tempest: The Arden Shakespeare. London: Methuen, 1954.

Loomba, Ania. Shakespeare, Race, and Colonialism. Oxford: Oxford University Press, 2002.

"Outsiders in Shakespeare's England" in The Cambridge Companion to Shakespeare. Cambridge: CUP, 2001

Markley, Robert. The Far East and the English Imagination, 1600-1730. Cambridge: Cambridge University Press, 2006.

Nietzsche, Friedrich Wilhelm. Thus Spoke Zarathustra: A Book for All and None. Graham Parkes trans. New York: Oxford University Press, 2005.

Shakespeare, William. Othello and The Tempest in The Complete Works of Shakespeare. Hertfordshire: Wordsworth Editions, 1996.

Skura, M. Anne. "Discourse and the Individual: The Case of Colonialism in The Tempest". Source: Shakespeare Quarterly, Vol. 40, No. 1 (Spring, 1989), pp. 42-69 Published by: Folger Shakespeare Library in association with George Washington University Stable URL: $\underline{\text { http://www.jstor.org/stable/2870753 }}$ 
Strach[e]y, William. "A True repertory of the wreck and redemption of Sir Thomas Gates, July 15, 1610", in Purchas His Pilgrimes. Vol. XIX. Glasgow: MacLehose; New York: Macmillan, 1906.

Turler, Jerome. The Traveiler.(1575) Intro. by Denver Ewing Baughan. Gainesville: FL: Scholars' Facsimiles and Reprints, 1951.

Vaughan, Virginia Mason. Othello: A Contextual History. Cambridge: Cambridge University Press, 1994.

Wilson, Richard." Voyage to Tunis: New History and the Old World of The Tempest." ELH, Vol. 64, No. 2 (Summer, 1997), Published by: The Johns Hopkins University Press.

For Dreyfus' quotation concerning Foucault:

http://ist-socrates.berkeley.edu/ hdreyfus/html/paper being.html

For 'privateering': http://www.thefreedictionary.com/Privateering. Also see Kenneth Andrews' Elizabethan Privateering: English Privateering during the Spanish War, 1585-1603.

For Cinthio's “Un Capitano Moro”: http://en.wikipedia.org/wiki/Othello.

For Behn as a Royalist: http://en.wikipedia.org/wiki/Oroonoko 